\title{
"State medical provision and health financing in Ukraine as compared to the experience of western European countries"
}

\begin{tabular}{|c|c|}
\hline \multirow{3}{*}{ AUTHORS } & Inna Neskorodieva (D https://orcid.org/0000-0002-7750-777X \\
\hline & Volodymyr Rodchenko (D https://orcid.org/0000-0003-0298-4747 \\
\hline & Olena Parkhomenko (D https://orcid.org/0000-0002-6492-6836 \\
\hline ARTICLE INFO & $\begin{array}{l}\text { Inna Neskorodieva, Volodymyr Rodchenko and Olena Parkhomenko (2018). } \\
\text { State medical provision and health financing in Ukraine as compared to the } \\
\text { experience of western European countries. Public and Municipal Finance, 7, 41- } \\
\text { 57. doi:10.21511/pmf.07(4).2018.05 }\end{array}$ \\
\hline DOI & http://dx.doi.org/10.21511/pmf.07(4).2018.05 \\
\hline RELEASED ON & Friday, 03 May 2019 \\
\hline RECEIVED ON & Wednesday, 27 February 2019 \\
\hline ACCEPTED ON & Tuesday, 02 April 2019 \\
\hline & \begin{tabular}{|l|l|l|l|l|}
$(c)$ \\
\end{tabular} \\
\hline LICENSE & $\begin{array}{l}\text { This work is licensed under a Creative Commons Attribution } 4.0 \text { International } \\
\text { License }\end{array}$ \\
\hline JOURNAL & "Public and Municipal Finance" \\
\hline ISSN PRINT & $2222-1867$ \\
\hline ISSN ONLINE & $2222-1875$ \\
\hline PUBLISHER & LLC “Consulting Publishing Company "Business Perspectives" \\
\hline FOUNDER & LLC “Consulting Publishing Company "Business Perspectives" \\
\hline$\delta^{\infty}$ & 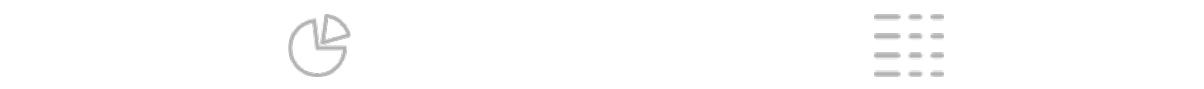 \\
\hline NUMBER OF REFERENCES & NUMBER OF FIGURES \\
\hline 91 & 2 \\
\hline
\end{tabular}

(c) The author(s) 2022. This publication is an open access article. 


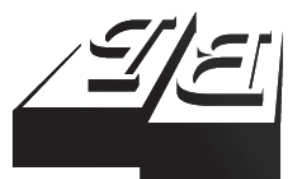

BUSINESS PERSPECTIVES

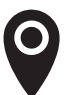

LLC "CPC "Business Perspectives" Hryhorii Skovoroda lane, 10, Sumy, 40022, Ukraine

www.businessperspectives.org

Received on: $27^{\text {th }}$ of February, 2019 Accepted on: $2^{\text {nd }}$ of April, 2019

(C) Limited Liability Company "Consulting Publishing Company

"Business Perspectives", 2018

Inna Neskorodieva, Ph.D. in Economics, Associate Professor, Karazin Business School, V. N. Karazin Kharkiv National University, Ukraine.

Volodymyr Rodchenko, Doctor of Economics, Professor, Karazin Business School, V. N. Karazin National University, Ukraine.

Olena Parkhomenko, Ph.D. in Economics, Asociate Professor Karazin Business School, V. N. Karazin National University, Ukraine.
Inna Neskorodieva (Ukraine), Volodymyr Rodchenko (Ukraine), Olena Parkhomenko (Ukraine)

STATE MEDICAL PROVISION AND HEALTH FINANCING IN UKRAINE AS COMPARED TO THE EXPERIENCE OF WESTERN EUROPEAN COUNTRIES

\section{Abstract}

In Ukraine, there is a steady increase in the mortality rate of the population, which is due to the low quality of medical provision. The main advantages and the efficiency factor of the health care system in the Western European countries are analyzed; the key factors regulating medical provision in Ukraine are systematized; the effectiveness of modern health care reform in Ukraine is evaluated; practical recommendations to improve the administrative and legal regulation of the system are developed. The analysis showed that the effectiveness of health care reform in Ukraine is currently about $30 \%$, and the high mortality rate of the population in Ukraine is primarily due to the low quality of medical care and inadequate investment in the industry. The main health problems in Ukraine are failure to comply with legislation on the amount of funding and remuneration in the public health system, high levels of corruption and lack of control over the competence of doctors, inaccessibility of medical products for consumers due to the pharmaceutical market monopolization.

Keywords

health care, public expenditure, budget, health insurance, quality of medical provision

\section{JEL Classification G28, H51}

\section{INTRODUCTION}

Medical provision refers to the independent function of state power and local self-government. It is based on special legislation, a system of government bodies that ensure the realization of the citizens' rights to receive health care services, sources of financing, and methods of their implementation (Sun et al., 2015; Murphy, Lawton, \& Sandel, 2015). The Western European health system is recognized as one of the most effective in the world. These countries have a high level of funding (on average up to $10 \%$ of GDP), a low mortality rate of the population (up to 8 people per 1,000 population) and a high level of medical support quality (in the first 20 countries according to the health care quality in the world) (OECD, 2019; Numbeo, 2019; World Health Organization, 2019a).

As a country of the post-Soviet space, Ukraine inherited the Semashko system-based health services (Andronik, 2017). The system is about ensuring equal access to health facilities for the entire population; provision of full medical care, lack of financial restrictions for citizens with different income levels; the presence of an integral system of treatment, prevention, rehabilitation and sanitary and epidemiological supervision; high qualification of personnel (Balabanova, Richardson, \& Coker, 2017). Only medicines received outside hospitals remained paid for patients. At the legal level, this system is reflected in the Constitution of Ukraine, according to which health care 
is provided by sanitary and preventive, health and fitness, sanatorium-resort, pharmaceutic, scientific and medical and other health care institutions (Verkhovna Rada of Ukraine, 1996). Ministry of Health of Ukraine is a specially authorized central executive body in the field of health. Its competence is determined by the provision approved by the Cabinet of Ministers of Ukraine. Thus, in Ukraine there is a three-step system of health care management and this system is extremely inefficient.

\section{LITERATURE REVIEW}

The Ukrainian health care system is based on primary medical and preventive care, which is provided by general practitioners mainly on an area basis. The principle of access to therapeutic and preventive care is implemented by Article 49 of the Constitution of Ukraine, according to which everyone has the right to health protection, medical care and medical insurance (Verkhovna Rada of Ukraine, 1996). Health protection is provided by public funding of relevant socio-economic, health and sanitary, as well as health-improving and preventive programs. The state creates conditions for effective and affordable health care for all citizens. In state and municipal health care facilities, free medical treatment is provided; the existing network of such institutions cannot be reduced. The state promotes the development of medical institutions of all forms of ownership.

Meanwhile, the mortality rate in Ukraine is one of the highest in the world. It amounted to $13.9 \%$ per 1,000 population as of 2017 . The country ranks 5 th in terms of the death rate in the world, giving place only to countries like Monaco (18.6\%), Bulgaria (15.1\%), Lithuania (14.4\%) and Latvia (14.3\%). With that, according to the latest World Health Organization (WHO) 1981-2017 data, the country's mortality rate increased by $2.6 \%$ (World Health Organization, 2019a; Central Intelligence Agency, 2019).

The average rate of increase in mortality over the study period exceeded the rate of population growth by $4 \%$, which is accompanied by a sharp decline in medical facilities in the country (over the past 27 years, by $44 \%$ with an almost unchanged incidence rate of the population). Over the past ten years, the population of Ukraine has decreased by $7.7 \%$, while the incidence has increased significantly in most diseases.

Life expectancy in Ukraine is 11 years less than in the EU countries (CantyMedia, 2018). The main factors of high mortality in Ukraine are coronary heart disease, blood stroke and oncology (Poniakina \& Shevchuk, 2017), which indicates the poor quality of health care in the country. So, according to official Numbeo data, the Ukrainian health system is in the $77^{\text {th }}$ place in terms of quality rating from 84 countries of the world (the Health Care Index 2019 value was 50.95) and almost in the very last place among European countries (Numbeo, 2019).

According to the WHO health rating, Ukraine ranks 97th out of 156, giving way to not only developed Western countries, but also the entire former USSR: Belarus is in the $54^{\text {th }}$ place, Russia is the $73^{\text {rd }}$ place, and Moldova ranks $75^{\text {th }}$. Only residents of poor Arab countries, Africa and Afghanistan have worse health and medical care than Ukrainians (Ivanova, 2018). One of the significant reasons is the low proportion of government funds for health care. In 2018, the level of financing in Ukraine amounted to $3.5 \%$ of GDP as compared to 7.01\% of GDP in 1995 (State Statistics Service of Ukraine, 2018).

According to the Law of Ukraine "On the State Budget for 2019", spending on health care is planned to increase by UAH 9.5 billion. However, taking into account the fact that it is also planned to increase the country's GDP to UAH 3,946.9 billion (UAH 3,332.3 billion in 2018), the indicator of financing health care decreases to $3.2 \%$ of GDP (Verkhovna Rada of Ukraine, 2018; Cabinet of Ministers of Ukraine, 2018). This indicator contradicts the WHO recommendations of at least 6\% of GDP and the requirements of the fifth part of Article 4 of the Law of Ukraine "On state financial guarantees of medical care for the population" on the costs of implementing a program of medical guarantees of at least $5 \%$ of GDP (the need is UAH 197 billion) (Verkhovna Rada of Ukraine, 2017a).

According to the 2017 annual report of the Ministry of Health of Ukraine, almost every 


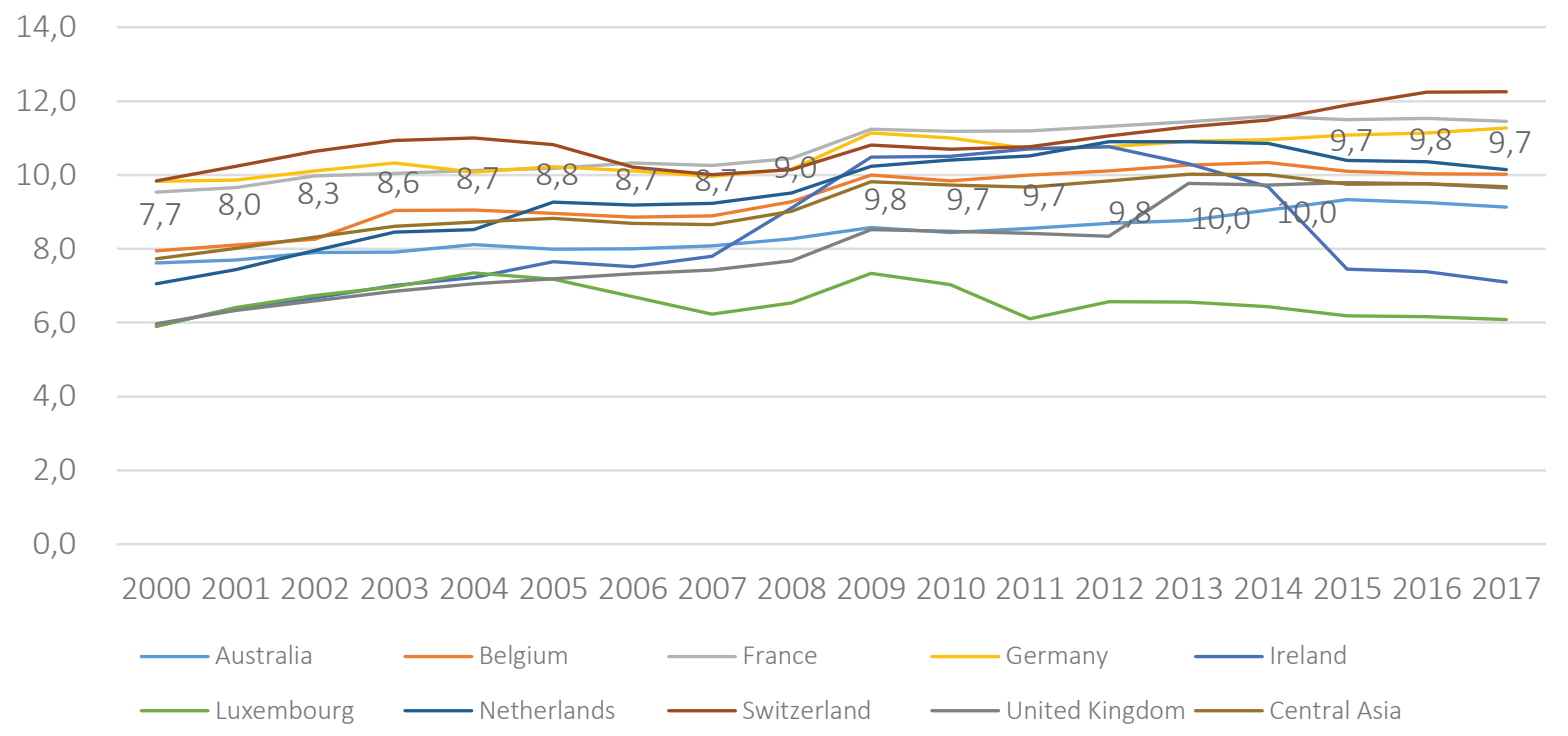

Figure 1. Dynamics of health financing in the Western European countries (\% of GDP)

sixth child has health abnormalities already at birth. Only $10 \%$ of first-graders start studying fully healthy, and by the fifth form only $1.5 \%$ of them remain (Kozachenko, 2018). In view of the above, it can be stated that the current critical situation in the health care system of Ukraine is primarily due to the imperfect administrative and legal regulation. On September 1, 2017, the Ukraine-EU Association Agreement entered into force (Official Journal of the European Union, 2014). This means that all further legislative initiatives should be considered in the context of European integration.

The health care reform proposed by the Ministry of Health of Ukraine contradicts the European integration course of Ukraine and has significant corruption risks.

Until now, the Constitution of Ukraine is at the head of legal acts. It creates a legal framework in the health care system governing relations in the medical care provision at all levels of social life (Verkhovna Rada of Ukraine, 1992). Due to the fact that the Constitution is a fundamental document, against the background of health care reform, its practical implementation will inevitably come into conflict with Article 49 of the Constitution (Verkhovna Rada of Ukraine, 1996). The legal regulation of the financial part of the medical services provision, as well as the mechanism of medical support, will be one of the debatable issues.
According to EU legislation, all citizens must have access to health care. There are differences between individual countries regarding the range of services, depending on the type of health financing. However, despite these differences, there is a social consensus that the health care at the level of diagnostics and therapy, regardless of their cost, must be accessible to all (Portal of The Publications Office of the EU, 2012; European Commission, 2014; European Union Agency for Fundamental Rights, 2018). This goal is critical for the administrative and legal regulation of health care in the EU.

Today, the quality of the health care system in Western Europe is one of the best in the world. Over the past 17 years, the average level of financing has increased by $2.7 \%$ of GDP. It should be noted in general that for the period 2000-2017, there is a positive trend in the medical industry financing in Western Europe, with the minimum value of health financing being always above $6 \%$ of GDP. The highest level of financing can be observed in Switzerland. As of 2017, it was 12.3\% of GDP, in France, it accounted for 11.5\% of GDP, in Germany - 11.3\% of GDP (see Figure 1) (OECD, 2019). These are countries where the death rate is one of the lowest in the world.

In Western European countries, there is a complex combination of the private and public sectors both in health financing and in health care deliv- 
ery (European Commission, 2014; Vogler, 2018). It is the budget financing model (the Beveridge Model), according to which the public sector accounts for the majority of the cost of maintaining health care facilities. This model has become widespread in the UK and Spain, where the state finances more than $80 \%$ of all medical care expenses (OECD, 2019). The insurance financing model (the Bismarck Model), which provides support to the health care sector from three sources: contributions from business structures, employees and the state, with $10-20 \%$ of the cost of medical services paid from the personal funds of citizens, is used in European countries such as France, Germany, Austria, Switzerland, the Netherlands, and Belgium (Busse et al., 2017; De Pietro \& Crivelli, 2015; Pierre \& Jusot, 2017). Such a system of health financing on insurance principles allows to increase the amount of financing by 1.5-2 times compared with the budget model (Boone, 2018). A wide range and almost unlimited amount of medical services are provided both at the hospital and at the outpatient level, and health consumers have the freedom to choose a service provider.

The UK National Health Service (NHS) is the most well-known universal medical care system in the world. It is a state system, funded mainly through taxes and providing services to all segments of the population on a grant basis mainly. The NHS is financed by the joint taxation system (95\%) and other payments (5\%) within the framework of the general budget, which is developed by the Ministry and adopted by the Parliament (The Statistics Portal, 2019). The payment system for general practitioners is a combination of fees and specific payments determined by their contracts. The main form of payment is capitation for each patient of a given doctor. The level of payment depends on the patient age. Some services (such as contraception or vaccination) are covered by a separate item (The National Archives, 2012). The cost of drugs is not refundable to consumers. Prices are set by manufacturers, but profits are controlled by the central government (The Commonwealth Fund, 2019b). The patient pays the total price of medical drugs that are available without a prescription; total payment for prescription drugs is based on a flat rate, with an average of $24 \%$ of the price of medicines paid by the patient (The Commonwealth Fund, 2019b).
Administrative and legal regulation and financing of the health care system in Germany is based on the traditional principles of social solidarity, decentralization and self-regulation. The role of the central government is limited to the development of a legal framework within which health services are provided, while the administrations of individual lands perform the main executive functions (The National Center for Biotechnology Information (NCBI), 2018). The Federal Ministry of Health is the main institution at the federal level, which includes scientific investigation agencies. The compulsory health insurance system covers about $88 \%$ of the population (13\% of them are voluntary) (Statistisches Bundesamt (Destatis), 2019). The program is funded by contributions from employees and employers. The average contribution is $13.52 \%$ (13.92\% in Eastern lands) (The Commonwealth Fund, 2019d; World Health Organization, 2019e). The employee always pays $6.76 \%$ (in the East, he pays $6.96 \%$ ) of his wages, the employer pays the same percentage on average, but this rate is different for different lands and foundations and ranges from 4.75 to $7.5 \%$. Approximately $60 \%$ of the funding comes from compulsory or voluntary contributions, $21 \%$ from general taxes, $7 \%$ from private insurance, and the remaining $12 \%$ are covered by direct payments from patients (The Commonwealth Fund, 2019d). Medical institutions, both private and public, are funded in a double way: it is assumed that the government will cover the capital expenditures of the land, and the operating expenses will be paid by the sickness funds. Hospital services for the insured privately are covered in accordance with the individual rates (Busse et al., 2017).

In Germany, the common prices for medicines are set. The cost of most drugs is reimbursed by the abstract pricing system (The Commonwealth Fund, 2019d). The doctor has the right to prescribe a more expensive product to the patient, but the patient will have to pay the difference between the actual price and the abstract price of the medication. The level of co-payment for drugs in Germany is one of the lowest in the $\mathrm{EU}$ (Busse et al., 2017).

The Dutch health system is financed largely by a combination of social and private insurance, with $64 \%$ of the population covered by social insurance and $31 \%$ by private insurance (Ministry of Public Health, Welfare and Sport, 2016). The compulsory 
health insurance program (CHIP) is provided by approximately 40 sickness funds and covers about $64 \%$ of the country's population. There is an income threshold that excludes a significant portion of the population (about $31 \%$ ) from this program - mainly high-income groups and self-employed (Ministry of Public Health, Welfare and Sport, 2016). They should buy private health insurance to cover the cost of acute illness. Civil servants make up approximately $5 \%$ of the country's population. They are insured by a special mandatory program, the services in which are larger in volume than in the CHIP system. In addition, members of social health insurance funds may purchase supplemental insurance to cover additional risks. Also, 90\% of the members of sickness funds use additional insurance to cover the cost of dental services (The Commonwealth Fund, 2019a). The Ministry of Public Health, Welfare and Sport is the main body responsible for planning and implementing health policy (The Commonwealth Fund, 2019a).

Social insurance is the dominant form of health financing in the Netherlands, covering about $70 \%$ of health costs. Personal insurance covers $13 \%$ of all expenses (The Commonwealth Fund, 2019a). Funding is supplemented by direct co-payment by patients and government subsidies. The Ministry submits a total budget for health expenditure to Parliament for approval. In addition, for some health care system sectors, cost targets for inpatient and outpatient care are established. Contributions to sickness funds are based on income and are mainly paid by the employer (5.6\% of gross income); the amount of the employee's contribution is significantly lower $(1.55 \%$ of gross income). There is an upper limit on income for contributions, 29.314 euros per annum (Belastingdienst, 2019a). Contributions are managed and distributed through the central fund and based on the principle of per capita financing partially taking risk into account. In addition, health fund members pay a small fixed amount, which is set by each health insurance scheme separately (180 euros on average). This fixed contribution covers approximately $10 \%$ of all health expenditure (Belastingdienst, 2019b).

In France, there are parallel systems of the private and public sectors, in funding and in the health care delivery. The health system is based on the mandatory state health care program, which is largely complemented by voluntary insurance. However, in general, the system covers almost the entire population of the country. A wide range and almost unlimited amount of medical services are provided both at the inpatient and at the outpatient level. Patients have the freedom to choose a service provider. Some family doctors and hospitals have local arrangements with reciprocal partners to reduce payments at the point of care.

The health care system in France is largely regulated by the government. At the local level, there are 22 regional offices for health and social affairs (DRASS). General access to medical services is guaranteed by the national health insurance system, which is part of the compulsory social support system and covers $99 \%$ of the country's population (European Observatory on Health Systems and Policies, 2017).

The general insurance program is financed by collecting taxes from employers and employees $12.8 \%$ of the cost of wages from the employer and $0.75 \%$ from the employee - and covers $74 \%$ of all health care expenditure. Joint companies cover about $7 \%$, and private insurers account for $5 \%$ of health care expenditure. Less than 3\% comes from a general tax collection, and the rest - above $12 \%$ comes from a patient's co-payment (Rodwin, 2018).

Pharmaceutical drugs are included in the list of drugs the costs for which are reimbursed. Prices and reimbursement are determined by order of the Ministry of Social Affairs and Health. Over the - counter (OTC) drugs, the cost of which is not covered by insurance, are not regulated. Patients' direct payments for drugs amount to $20 \%$ on average, although they can range from zero (necessary drugs) to $65 \%$ for so-called "comfort drugs". In France, there is no budget limit for pharmaceuticals, and no restrictions on the prescriptions (The Commonwealth Fund, 2019c).

As for Ukraine, diseases account for the lion's share (86.8\%) of all causes of mortality (Rating Group Ukraine, 2016; Health Statistics Service of Ministry of Health of Ukraine, 2019) (see Figure 2).

At the same time, Ukraine is not inferior to more developed countries, such as Poland and France, 
Table 1. Comparison of health systems quality and efficiency

\begin{tabular}{|c|c|c|c|c|c|}
\hline Country & $\begin{array}{c}\text { Risk of death from } \\
\text { noncommunicable } \\
\text { diseases (30 to } 70 \\
\text { years old) }\end{array}$ & $\begin{array}{l}\text { The number } \\
\text { of doctors per } \\
100 \text { thousand } \\
\text { population }\end{array}$ & $\begin{array}{c}\text { The number of } \\
\text { deaths in childbirth } \\
\text { (per } 100 \text { thousand } \\
\text { population) }\end{array}$ & $\begin{array}{l}\text { The presence of } \\
\text { qualified medical } \\
\text { staff in childbirth }\end{array}$ & $\begin{array}{c}\text { Number of hospital } \\
\text { beds per 100,000 } \\
\text { population }\end{array}$ \\
\hline Ukraine & $28 \%$ & 315 & 23 & $99 \%$ & 784 \\
\hline Poland & $20 \%$ & 231 & 3 & $100 \%$ & 663 \\
\hline Germany & $12 \%$ & 411 & 7 & $98 \%$ & 823 \\
\hline France & $11 \%$ & 323 & 8 & $97 \%$ & 641 \\
\hline USA & $14 \%$ & - & 28 & $99 \%$ & - \\
\hline
\end{tabular}

in the number of doctors per 100 thousand population, and even exceeds them significantly in the number of hospital beds (see Table 1) (Health Statistics Service of Ministry of Health of Ukraine, 2019; World Health Organization, 2018).

In 2018, the health care reform in Ukraine started to be implemented. It was designed to reduce the mortality rate in the country and improve the quality of medical support for Ukrainians. Legislative changes in the reform process will affect not only the sphere of medical services financing, but also the entire system of legal regulation of the health care industry, since it is the problems of its functioning that are the main cause of the low quality of medical provision. The following measures have become the prerequisites and made the basis of the health care reform: the Law of Ukraine "On state financial guarantees for the provision of health care and medicines" (No. 6327) (Cabinet of Ministers of Ukraine, 2017b) adopted by Verkhovna Rada of Ukraine; the draft law on the necessary changes to the state budget (No. 6604) (Cabinet of Ministers of Ukraine, 2017a), and the presidential draft law "On increasing the availability and quality of health care in rural areas" (No. 7117) (LigaZakon, 2017b), the Law of Ukraine "On state financial guarantees for health care for the population" (Verkhovna Rada of Ukraine, 2017a), the draft law No. 6634 "On primary care on the principles of family medicine" (which was rejected by Verkhovna Rada of Ukraine) (LigaZakon, 2017a). The beginning of the health care reform has only affected the primary level: Ukrainians sign declarations with general practitioners, family doctors or pediatricians. It is for the assigned patients that the doctor now receives a salary. For one person, the therapist, family doctor and pediatrician will receive 370 hryvnias per year. For children and the elderly, the National Health Service will pay more, 740 hryvnias (Сегодня [Segodnia], 2018b). Attention, however, should be paid to the fact that nowadays in Ukraine, family doctors, district therapists and pediatricians who, according to the Ministry of Health decree, are authorized to conclude a declaration, amount to less than $50 \%$ of the required number (Сегодня [Segodnia], 2018a). According to the documents, there are about 14 thousand family doctors prepared; 7-8 thousand actually work, and 30 thousand are needed (Obozrevatel. ua, 2018). Patients usually sign declarations with doctors whom they trust, and other doctors receive the previous level of wages, which in turn results in a decline in the prestige of the medical profession and a corresponding reduction in the number of potential personnel. Thus, the extremely low wages do not provide health workers with even the minimum cost of living. According to the State Statistics Service of Ukraine, in June 2018, the average salary level of health workers was $6,258 \mathrm{UAH}$, which is 1.5 times less than in the industrial sector (9,552 UAH), 1.4 times less than in the field of education $(8,553 \mathrm{UAH})$, and 1.1 times less than in the field of culture $(6,641$ UAH) (State Statistics Service of Ukraine, 2019). And this is despite the fact that, according to the Law of Ukraine "On state financial guarantees of health care for the population", the Law of Ukraine "On increasing the availability and quality of health care in rural areas" and the Law of Ukraine "On emergency medical care", there should be an increase in the capitation wage rate for health workers at the rate of not less than $250 \%$ of the average salary in Ukraine for July 2017 (Konoval \& Gul, 2018). In addition, in 2018, the medical subvention amounted to UAH 57.4 million, while the wage fund deficit amounted to about UAH 3.6 billion. This resulted in salary arrearage to employees of health institutions in 11 Ukrainian regions in the amount of UAH 98.2 million (State Statistics Service of Ukraine, 2019). 
In the context of reforming the Ukrainian health care system aimed at raising its financing and taking into account the indicators of the Law of Ukraine "On the state budget for 2019", it can be argued that the existing problems have been totally ignored. It is envisaged for 2019 that the amount of medical subventions will be UAH 55,502,068.3 thousand, which is UAH 1.9 billion less than in 2018. Whereas, based on the provisions of the Cabinet of Ministers of Ukraine Resolution No. 524 dated May 11, 2011 (Cabinet of Ministers of Ukraine, 2011a), the need is calculated based on the minimum wage from January 1, 2019 and the $1^{\text {st }}$ tariff category of the Unified Rate Schedule (URS) (Интерактивная бухгалтерия [Interaktivnaya bukhgalteriya], 2019). The payroll budget (with extra fee) should be UAH 89,070.1 million. That is, the wage differentiation criteria for health care workers are completely leveled. The World Health Organization recommendations were also totally ignored. Articles 7 and 8 of the draft state budget provide for the establishment of a minimum standard of living for able-bodied persons in Ukraine from January 1, 2019 in the amount of UAH 1,921 and the minimum wage in the amount of UAH 4,173 (Verkhovna Rada of Ukraine, 2018). Consequently, from January 1, 2019, the amount of the basic tariff category of the URS is only $46 \%$ of the minimum wage, and the existing equalization in remuneration from the $1^{\text {st }}$ to the $11^{\text {th }}$ URS tariff category will not only be preserved, but will also spread to the $13^{\text {th }}$ tariff category (Интерактивная бухгалтерия [Interaktivnaya bukhgalteriya], 2019). Consequently, for health care workers, a salary at the level of the minimum wage has been established.

Chronic underfunding of health care provokes payment for treatment at the expense of patients, which violates Article 49 of the Constitution of Ukraine. So, during the period 2004-2018, the proportion of household spending on health care has steadily increased and in 2018 reached $4.7 \%$ of the total household expenditure as compared to $2.8 \%$ in 2004 . While public funding decreased by $1.1 \%$ for the period under study (Ministry of Finance of Ukraine, 2018). The current situation causes a change in the moral and ethical attitude of health care workers towards the sick, and, accordingly, of patients towards doctors. With the constitutional right to free medicine, the health care sector in Ukraine is recognized as one of the most corrupted social spheres in the country. So, out of UAH 120 million losses against the state, $90 \%$ of the funds were lost due to corruption offenses in the field of health care (National AntiCorruption Bureau of Ukraine, 2018). In this case, for refusal to treat or for extortion of money from a patient, a doctor can be put in jail. According to Article 184 of the Criminal Code, for violating the right to free medical care, a fine of $170 \mathrm{UAH}$ up to six months of arrest are provided for (Criminal Code of Ukraine, 2001). The low level of remuneration in the health system and the high level of its corrupt practices provoke emigration of doctors from Ukraine. According to a BBC News investigation, about 66 thousand health professionals left Ukraine (Dorosh, 2018).

Access to health care facilities and ensuring a balance of interests between patent holders and consumers of pharmaceutical services are the basic components of health care and high-quality medical care. Nowadays in Ukraine, according to the USAID project results, every second patient in Ukraine refuses treatment due to lack of money (Страна.ua [Strana.ua], 2017). This is despite the fact that many Ukrainians buy drugs at their own expense, although according to the law of Ukraine they should receive drugs free of charge from the state (Verkhovna Rada of Ukraine (1996) Constitution of Ukraine, Art. 49). One of the reasons for the current situation is that more than $60 \%$ of Ukrainians are below the poverty line today. It should be noted, however, that this factor is not key in the lack of drugs availability for the population in the country.

\section{METHODS}

Given the lack of legally approved indicators, which would allow to evaluate the effectiveness of the health care reform implementation, an expert assessment was conducted as part of the study. Lawyers can assess accurately the effectiveness of the health care reform implementation in Ukraine in the legislative plane; economists can do this appropriately when it comes to the financial plane; in organizational terms, lawyers and economists, while doctors and patients are subjects of medical relations. In the regional con- 
text, the study was conducted in Kyiv, Kharkiv, Lutsk, Kherson and Chernihiv. The use of such a broad geography (center, south, west, east, north) made it possible to take into account the mood and readiness for the reform of the participants throughout Ukraine, regardless of political beliefs. In addition, respondents represent cities with different levels of economic development in order to draw adequate conclusions about the feasibility of implementing the financial component of the reform.

A test of the representativeness of the research results was conducted according to the sample sufficiency indicator (Ponto, 2015).

According to calculations, the sample will be characterized by the sufficiency principle in a large general sample (more than 30 people), if the number of respondents exceeds 273 people. 300 people took part in the study. The reliability of the sample, its randomness, diversification according to geographic, economic, and professional characteristics indicate the representativeness of the research results and the possibility of taking them into account when implementing health care reform in Ukraine. Expert assessment was conducted via face-to-face questionnaires.

Respondents were asked to put their rate on a 5 -point scale for the following positions (three statements in each of the three blocks). " 5 " corresponded to the highest level of readiness for reform, at which concrete measures towards the reform implementation are remarkable. A rate of " 0 " corresponds to the categorical disagreement of the respondent with the possibility of taking a certain type of measures for the health care reform implementation.

Here are the positions according to which the health care reform effectiveness in Ukraine was assessed:

1. Legislative support:

1.1. In Ukraine, the laws started to be adopted promoting the reform implementation.

1.2. The legislation has eliminated all contradictions in the healthcare field.
1.3. All legal provisions contributing to the reform implementation are implemented.

2. Financial support:

2.1. Standard for funding health care is met in the country.

2.2. The state finances provision of health services and the purchase of medicines to the population.

2.3. An adequate level of medical workers' remuneration has been ensured.

3. Organizational support:

3.1. The system of compulsory health insurance is active.

3.2. Transferring the duties of other doctors to the family doctor is justified from the standpoint of ensuring medical efficacy.

3.3. The mortality problem has been solved in Ukraine.

\section{RESULTS}

Table 2 presents the expert evaluation results of the effectiveness of the health care reform implementation in Ukraine aimed at addressing the problems identified in the functioning of the health system.

The practice of administrative and legal regulation of health care provision in Western countries shows that the most effective is the combination of state budgeting and a certain system of health insurance. The advantage of state budgeting is that in this way the constitutional right of a citizen to receive free medical care is realized, thereby ensuring a high degree of social protection. The research conducted made it possible to state that an effective health care system rests on the regulating a specific list of services and the sources of their financing. The amount of financing of health care institutions depends not on the number of services provided and patients accepted, but on the health care quality and treatment of patients. The 
Table 2. Expert assessment of health care reform in Ukraine to ensure quality medical care for the population

\begin{tabular}{|c|c|c|c|}
\hline Statement & $\begin{array}{l}\text { Mean } \\
\text { score }\end{array}$ & $\begin{array}{c}\text { Probable } \\
\text { maximum score }\end{array}$ & $\begin{array}{l}\text { Readiness } \\
\text { indicator, \% } \\
\end{array}$ \\
\hline $\begin{array}{l}\text { 1.1. In Ukraine, the laws started to be adopted promoting the reform } \\
\text { implementation }\end{array}$ & 4.7 & 5 & 94.0 \\
\hline 1.2. The legislation has eliminated all contradictions in the healthcare field & 2.5 & 5 & 50.0 \\
\hline $\begin{array}{l}\text { 1.3. All legal provisions contributing to the reform implementation are } \\
\text { implemented }\end{array}$ & 1.9 & 5 & 38.0 \\
\hline Legislative support & 9.1 & 15 & 60.7 \\
\hline 2.1. Standard for funding health care is met in the country & 0 & 5 & 0.0 \\
\hline $\begin{array}{l}\text { 2.2. The state finances provision of health services and the purchase of } \\
\text { medicines to the population }\end{array}$ & 1.3 & 5 & 26.0 \\
\hline 2.3. An adequate level of medical workers remuneration has been ensured & 0.8 & 5 & 16.0 \\
\hline Financial support & 2.1 & 15 & 14.0 \\
\hline 3.1. The system of compulsory health insurance is active & 1.2 & 5 & 24.0 \\
\hline $\begin{array}{l}\text { 3.2. Transferring the duties of other doctors to the family doctor is justified } \\
\text { from the standpoint of ensuring medical efficacy }\end{array}$ & 2.2 & 5 & 44.0 \\
\hline 3.3. The mortality problem has been solved in Ukraine & 0 & 5 & 0,0 \\
\hline Organizational support & 3.4 & 15 & 22.7 \\
\hline Overall readiness indicator & 14.6 & 45 & 32.4 \\
\hline
\end{tabular}

constant growth of funding for the health care system ensures high quality of medical services, and government control over the pharmaceutical market guarantees the availability of medicines for consumers. In addition to the ministries, there is a professional self-management of medical workers - doctors, licensed pharmacist and nurses, which decentralize administrative and legal regulation of health care. The administrative and legal base of Western European countries provides professional self-governing organizations with a part of state authority in the field of professional relations, which ensures a high level of expertise of health professionals (The Commonwealth Fund, 2019a, 2019b, 2019c, 2019d). And most importantly, the health care system is motivated by and focused on the quality of medical services.

The study has found that the effectiveness of the health reform implementation in Ukraine is $32.4 \%$ (see Table 2). At the same time, the effectiveness of administrative and legal regulation in terms of health financing amounts to $14 \%$; organizational support - 22.7\%; and in terms of legislative support it amounts to $60.7 \%$ of which the maximum number of points falls at the beginning of the adoption of relevant legislative and regulatory acts to improve the quality of medical care in the country.

Based on the identified factors of the health system effectiveness in Western European countries, it is possible to single out the following directions for improving the administrative and legal regulation of health in Ukraine in order to contribute to effective implementation of health care reform. Modification of the regulatory framework governing health care, including laws on national health care, on the public and private health care systems, on making amendments to already existing laws directly or indirectly related to the administrative and legal regulation of health care should be based on: determining methods of health financing; improving the administrative structure of the health management system; creating a basic state package of free medical care; developing a policy of state support for regional medical institutions; developing new approaches to the pharmaceutical market (tight control of prices for essential medicinal drugs and government procurement of medicines for medical institutions, combined supply of medicines from the state budget and medical insurance).

Given the advanced experience of Western Europe, the goal of the new health care system in Ukraine should be to provide quality health care available to all segments of the population, which is possible subject to the introduction of compulsory health insurance along with budgetary funding. This means that health insurance requires certain government regulations and guarantees. The state should not only determine the amount of basic health care, but also guarantee its receipt to everyone in need. It is important to take into ac- 
count the practice of the Western European countries (securing the amount of health financing in the State Budget at least $6 \%$ of GDP) and approve the principle of a family doctor, not territorial affiliation, as the basis for health insurance. Such a concept would allow realizing the patient's right to choose a doctor and an appropriate insurance organization. To implement this concept, relevant health professionals should be trained and a legal mechanism for interaction between the family doctor and medical institutions should be developed. Contracts between health care economic entities should be the basis of this interaction. Contractual relationships can be drivers in the financial issues regulation. In this regard, additions are recommended to be written to the law of Ukraine "On state financial guarantees of public health service", Article 8, "Peculiarities of contracts on public health service under the program of medical guarantees" (Verkhovna Rada of Ukraine, 2017a). It is expedient to add the first paragraph with the following: "The subject of health care activity is recommended to enter into agreements on financial cooperation with public authorities on the one hand, and with health insurance organizations on the other". If bilateral agreement commitments are introduced into the health care system, environment for healthy competition among medical institutions can be created. This will improve the quality of medical services, implementing the right of choice, both by the patient and the medical institution of the health insurance organization, which in turn will create conditions for competition among the latter. It is important to understand that in a globalized economy, the key to the survival of any kind of industry, including health care, is its commercial basis (Sun et al., 2015).

Today in all places in Ukraine, there are facts of violation of the constitutional right of citizens to receive quality medical care. Patients who apply to medical institutions do not know what kind of services are payable by law. Medical staff often use ignorance of patients and provide a guaranteed amount of free health care on a paid basis. Therefore, along with the introduction of compulsory medical insurance, it is necessary to develop a system for monitoring the quality of medical services. Such a control system should be coupled with the improvement of administrative and legal responsibility, which is currently governed by the rules of the Code of Ukraine on Administrative Offenses (iFactor, 2019). It is expedient to add Article 5 "Administrative rights violations in the field of occupational safety and health protection" with the following points:

1) for concealing complete information from patients about the forthcoming treatment, not properly executing the necessary documentation on the provision of health services;

2) for the collection of money while providing health services included to the list of guaranteed free services;

3) for causing harm to health in the course of medical care and for significant harm to the patient as a result of medical error.

The above administrative measures will not only help prevent re-violation of legislation by health workers, but also significantly improve the quality of medical services provided to the population and allow the citizens to exercise their constitutional rights to health protection.

As mentioned earlier, the basis for developing a system for the protection of the rights of citizens in the health sector in Western European countries is the state's guarantee of respect for patients 'rights in the form of a regulatory framework (Sun et al., 2015). In the current legislation of Ukraine, the rights of patients are divided into various regulatory acts and regulations. Therefore, creating a Law "On the rights of patients", which is consistently structured and reduced to a common denominator with other regulatory acts, is an important task in the legal sector of state activity.

One of the most important areas of improving the administrative and legal regulation of the health care system in Ukraine should also be the elimination of the system of certification of doctors, regulated by the Ministry of Health of Ukraine dated December 19, 1997 No. 359 "On further improving the certification of doctors" (Ministry of Health of Ukraine, 1997). It is mandatory to develop the appropriate Law of Ukraine "On implementing the system of independent licensing of doctors", which will be based on continuous 
professional development. At the same time, the current licensing system of medical practice in accordance with the Law of Ukraine "On licensing types of economic activities" will remain generally unchanged (Verkhovna Rada of Ukraine, 2015). The regulation of creating a licensing system by law is more expedient, since changing the Law without public exposure is impossible, unlike the by-laws of the Ministry of Health of Ukraine. In the countries under study - France, Germany, the Netherlands, and the United Kingdom - the status of the bodies licensing doctors is defined at the level of laws (Portal of the Publications Office of the EU, 2012; The National Archives, 2012; European Commission, 2014). Ukraine has also the legislative practice to determine the legal status of bodies providing access to certain professions, namely laws (for example, the Audit Chamber of Ukraine, the Qualification Commission of Private Performers, the Council of Advocates of Ukraine, etc.) (Verkhovna Rada of Ukraine, 2017b; Verkhovna Rada of Ukraine, 2016; Ukrainian National BAR Association, 2012). To determine the criteria and requirements of the licensing system for doctors in Ukraine, members of the Licensing Board should involve associations of doctors and foreign experts (for example, from the European Medical Association) who may be members of tender commissions. It is also advisable to attract foreign experts to the Licensing Board as members or independent consultants. The composition of the Licensing Council must be approved by order of the Ministry of Health.

Since exercising the medical profession in the absence of a license will be prohibited, the new Law should regulate obtaining a license by already practicing (certified) doctors. Among the possible options for resolving the situation, one can see only the granting of a license subject to passing a special ex$\mathrm{am}$. In order to interest doctors in quickly switching to a new licensing model during the transition period in Ukraine, a communication campaign should be carried out for patients, they also should be informed about the license as proof of the doctor's professional qualifications and encouraged to seek qualified medical assistance from licensed doctors.

The Ministry of Health of Ukraine is the only central executive body that determines and implements the state policy in the field of health care, whereas in the Western European countries, apart from the Ministry, there is a professional self-government of medical workers - doctors, pharmacists and nurses. The laws in these countries provide professional self-governing organizations with a part of state authority in the field of professional relations. In general, attention should be paid to the fact that health care reform in Ukraine should begin with the adoption of legislation on public law professions. Only this will change the paradigm of the doctor and patient relationship. Creating a medical self-government body by giving force of law to the draft law "On medical self-government" is also needed (LigaZakon, 2018).

It is necessary to ensure payments stipulated by the decrees of the Cabinet of Ministers of Ukraine "On labor remuneration based on the Unified Rate Schedule of rates and levels on labor remuneration for institutions, agencies and organizations of certain sectors of the public sector" No. 1298 dated August 30, 2002 (Cabinet of Ministers of Ukraine, n.d.), "On approving the procedure for payment of a long service bonuses to health workers and pharmacists of state and municipal health care institutions" No. 1418 as of December 29, 2009, (Cabinet of Ministers of Ukraine, 2009), "Issues of remuneration of employees of institutions, agencies and organizations of individual sectors of state-financed sector" No. 524 as of May 11, 2011 (Cabinet of Ministers of Ukraine, 2011a), "About some measures to increase the prestige of labor of health workers who provide medical care to tuberculosis patients" No. 123 dated February 16, 2011 (Cabinet of Ministers of Ukraine, 2011b), "Some issues of remuneration of employees of tuberculosis institutions" No. 74 as of March 20, 2013 (Cabinet of Ministers of Ukraine, 2013c), "Some issues of remuneration of health workers of the emergency medical assistance" No. 199 as of March 27, 2013 (Cabinet of Ministers of Ukraine, 2013a), and "Some issues on remuneration of health workers who provide primary health care" No. 977 dated December 30, 2013 (Cabinet of Ministers of Ukraine, 2013b).

Changes in legislation in the field of licensing economic activities in the pharmaceutical market and the introduction of restrictions on the issuance of wholesale licenses to retailers are consistent with European approaches. 


\section{CONCLUSION}

The study concluded that the effectiveness of administrative and legal regulation of health care is ensured by the availability of comprehensive budget and commercial funding, tight control over the quality of medical services, guaranteed availability of medical products, and decentralization of the system of regulatory bodies for medical provision.

An expert analysis showed that the effectiveness of health care reform in Ukraine is currently $34.2 \%$, and this when the high mortality rate in the country is primarily due to the low level of quality of medical provision. The main problems of administrative and legal regulation of health care in Ukraine are non-compliance with legislation on the amount of funding and remuneration in the health care system, high levels of corruption and lack of control over the competence of doctors, inaccessibility of medical products for consumers due to the pharmaceutical market monopolization.

Given the advanced experience of medical provision in Western Europe, the developed set of recommendations for improving the administrative and legal regulation of the health care system is based on three components: legislative, financial and organizational support. The basis for improvement should be the creation of legislation on the licensing of doctors in Ukraine and the creation of self-governing medical organizations.

Thus, the recommendations proposed in the article are intended to contribute to the improvement of the current legislation in administrative and legal regulation of medical provision in Ukraine, thereby improving its quality and, as a result, raising the nation's health index to a higher level.

\section{REFERENCES}

1. Aleksandrova, O. Yu., \& Nagibin, O. A. (2015).

Стандарты медицинской помощи - значение понятия для конкретизации государственных гарантий бесплатности лекарственной медицинской помощи [Standarty meditsinskoy pomoshchi - znacheniye poniatiya dlia konkretizatsii gosudarstvennykh garantiy besplatnosti lekarstvennoy meditsinskoy pomoshchi]. Menedzher zdravookhraneniya, 3, 6-10. Retrieved from http:// www.idmz.ru/jurnali/menedgerzdravoohranenija/2015/3/ standarty-meditsinskoi-pomoshchi-znachenie-poniatiia-dliakonkretizatsii-gosudarstvennykhgarantii-besplatnosti-lekarstvennoi-meditsinskoi-pomoshchi

2. Andronik, V. (2017). Медицина в соседних странах и Украине: что ждет наше здравоохранение [Meditsina v sosednikh stranakh i Ukraine: chto zhdet nashe zdravookhranenie]. Сегодня [Segodnya]. Retrieved January 12, 2019 from https://www.segodnya.ua/ lifestyle/food_wellness/medicinav-sosednih-stranah-i-ukrainechto-zhdet-nashe-zdravoohranenie-1020294.html

3. Balabanova, D., Richardson, E., \& Coker, R. (2017). Russia and Former USSR, Health Systems of. In International Encyclopedia of Public Health (2nd ed.) (pp. 627-637)

4. Belastingdienst (2019a). Calculating the income-dependent contribution pursuant to the Health Care Insurance Act (Zvw). Retrieved January 10, 2019 from https:// www.belastingdienst.nl/wps/wcm/ connect/bldcontenten/belastingdienst/business/payroll_taxes/ you_are_not_established_in_the netherlands_are_you_required_ to_withhold_payroll_taxes/ when_you_are_going_to_withhold_payroll_taxes/calculating_payroll_taxes/calculating_the_ income-dependent_contribution_ pursuant_to_the_health_care_insurance_act_zvw
5. Belastingdienst (2019b). Zorgverzekeringswet. Retrieved January 10, 2019 from https://www.belastingdienst.nl/wps/wcm/connect/ bldcontentnl/belastingdienst/ prive/werk_en_inkomen/zorgverzekeringswet/

6. Boone, J. (2018). Basic versus supplementary health insurance: Access to care and the role of cost effectiveness. Journal of Health Economics, 60, 53-74. https://doi. org/10.1016/j.jhealeco.2018.05.002

7. Busse, R., Blümel, M., Kniepsc, F., \& Bärnighausen, T. (2017). Statutory health insurance in Germany: a health system shaped by 135 years of solidarity, selfgovernance, and competition. The Lancet, 390(10097), 882-897. https://doi.org/10.1016/S01406736(17)31280-1

8. Cabinet of Ministers of Ukraine (2009). Про затвердження Порядку виплати надбавки за вислугу років медичним та фармацевтичним працівникам державних та комунальних 
закладів охорони здоров'я. Постанова Кабінету Міністрів України від 29.12.2009 № 1418

[Pro zatverdzhennia Poriadku vyplaty nadbavky za vysluhu rokiv medychnym ta farmatsevtychnym pratsivnykam derzhavnykh ta komunalnykh zakladiv okhorony $z$ dorovia. Postanova Kabinetu Ministriv Ukrainy vid 29.12.2009 No 1418]. Retrieved January 18, 2019 from https://zakon.rada. gov.ua/laws/show/1418-2009$\% \mathrm{D} 0 \% \mathrm{BF}$ ?lang=ru

9. Cabinet of Ministers of Ukraine (2011a). Питання оплати праці працівників установ, закладів та організацій окремих галузей бюджетної сфери. Постанова КМУ вid 11.05.2011 p. № 524 [Рytaannia oplaty pratsi pratsivnykiv ustanov, zakladiv ta orhanizatsii okremykh haluzei biudzhetnoi sfary. Postanova KMU vid 11.05.2011 r. No. 524]. Retrieved January 15, 2019 from https://zakon.rada. gov.ua/laws/show/524-2011$\% \mathrm{D} 0 \% \mathrm{BF}$ ?lang=ru

10. Cabinet of Ministers of Ukraine (2011b). Про деякі заходи щодо підвищення престижності прачі медичних працівників, які надають медичну допомогу хворим на туберкульоз. Постанова Кабінету Міністрів України від 16.02.2011 № 123 [Pro deiaki zakhody shchodo pidvyshchennia prestyzhnosti pratsi medychnykh pratsivnykiv, yaki nadaiut medychnu dopomohu khvorym na tuberkulioz. Postanova Kabinetu Ministriv Ukrainy vid 16.02.2011 no. 123]. Retrieved January 18, 2019 from https:// zakon.rada.gov.ua/laws/show/1232011-\%D0\%BF?lang=ru

11. Cabinet of Ministers of Ukraine (2013a). Деякі питання оплати прачі медичних працівників системи екстреної медичної допомоги. Постанова Кабінету Міністрів України від 27.03.2013 № 199 [Deiaki pytannia oplaty pratsi medychnykh pratsivnykiv systemy ekstrenoi medychnoi dopomohy. Postanova Kabinetu Ministriv Ukrainy vid 27.03.2013 No. 199]. Retrieved January 18 , 2019 from https://zakon.rada. gov.ua/laws/show/199-2013$\% \mathrm{D} 0 \% \mathrm{BF}$ ?lang=ru
12. Cabinet of Ministers of Ukraine (2013b). Деякі питання оплати праці медичних прачівників, що надають первинну медичну допомогу. Постанова Кабінету Міністрів України; Порядок вid 30.12.2013 № 977 [Deiaki pytannia oplaty pratsi medychnykh pratsivnykiv, shcho nadaiut pervynnu medychnu dopomohu. Postanova Kabinetu Ministriv Ukrainy; Poriadok vid 30.12.2013 No 977]. Retrieved January 18, 2019 from https://zakon.rada. gov.ua/laws/show/977-2013$\% \mathrm{D} 0 \% \mathrm{BF}$ ?lang=ru

13. Cabinet of Ministers of Ukraine (2013c). Деякі питання оплати праці працівників протитуберкульозних закладів. Постанова Кабінету Міністрів України від 20.03.2013 № 174 [Deiaki pytannia oplaty pratsi medychnykh pratsivnykiv protytuberkulioznykh zakladiv. Postanova Kabinetu Ministriv Ukrainy vid 20.03.2013 No. 174]. Retrieved January 18, 2019 from https:// zakon.rada.gov.ua/laws/show/1742013-\%D0\%BF?lang=ru

14. Cabinet of Ministers of Ukraine (2017a). О внесении изменений в Бюджетный кодекс Украины относительно обеспечения государственных финансовых гарантий предоставления медицинских услуг и лекарственных средств. Проект закона Украины от 21.06.2017 № 6604 [O vnesenii izmeneniy $v$ Biudzhetnyy kodeks Ukrainy otnositelno obespecheniya gosudarstvennykh finansovykh garantiy predostavleniya meditsinskikh uslug i lekarstvennykh sredstv. Proekt zakona Ukrainy ot 21.06.2017 No. 6604]. Retrieved January 162019 from http:// search.ligazakon.ua/1_doc2.nsf/ link1/JH53G00A.html

15. Cabinet of Ministers of Ukraine (2017b). О государственных финансовых гарантиях предоставления медицинских услуг и лекарственных средств. Проект закона Украины от 10.04.2017 № 6327 [O gosudarstvennykh finansovykh garantiyakh predostavleniya meditsinakikh uslug i lekarstvennykh sredstv. Proekt zakona Ukrainy ot 10.04.2017
№ 6327]. Retrieved January 16, 2019 from http://search.ligazakon. ua/1_doc2.nsf/link1/JH4VR00A. html

16. Cabinet of Ministers of Ukraine (2018). Правительство прогнозирует рост ВВП Украины в 2019 от 1,1\% до 4,4\% [Pravitelastvo prognoziruyet rost VVP Ukrainy v 2019 ot 1,1\% do 4,4\%]. Retrieved January 14, 2019 from https://www.capital. ua/ru/news/116271-pravitelstvo-prognoziruet-rost-vvpukrainy-v-2019-ot-1-1-do-44\#ixzz5cvikvXF5

17. Cabinet of Ministers of Ukraine (n.d.). Об оплате труда работников на основании Единой тарифной сетки разрядов и коэфбициентов по оплате труда работников учреждений, заведений и организаций отдельных отраслей бюджетной сферы. (2002). Постановление КМ от 30.08.2002 № 1298 [Ob oplate truda rabotnokov na osnovanii Yedinoy tarifnoy setki razriadov $i$ koeffitsiyentov po oplate truda rabotnikov uchrezhdeniy, zavedeniy i organizatsiy otdelnykh otrasley biudzhetnoy sfery. Postanovleniye KM ot 30.08.2002 No. 1298]. Retrieved January 18, 2019 from http://search.ligazakon.ua/_ doc2.nsf/link1/KP021298.html

18. CantyMedia (2018). The World: Life Expectancy. Retrieved January 09, 2019 from http://www.geoba. se/population.php?pc=world\&typ $\mathrm{e}=015 \&$ year $=2018 \&$ st $=$ country $\& \mathrm{a}$ sde $=$ \&page $=2$

19. Central Intelligence Agency (2019). The World Factbook. Retrieved January 10, 2019 from https://www.cia.gov/library/publications/the-world-factbook/geos/ up.html

20. De Pietro, C., \& Crivelli, L. (2015). Swiss popular initiative for a single health insurer... once again! Health Policy, 119(7), 851-855. https://doi.org/10.1016/j.healthpol.2015.05.004

21. Dorosh, S. (2018). Эмиграция врачей из Украины: будет ли кому лечить? [Emigratsiya vrachey iz Ukrainy: budet li 
komu lechit?] BBC News Украина [BBC News Ukraina]. Retrieved January 18, 2019 from https:// www.bbc.com/ukrainian/featuresrussian-45110675

22. European Commission (2014). Communication from The Commission. On effective, accessible and resilient health systems. Retrieved January 15, 2019 from https:// ec.europa.eu/health/sites/health/ files/systems_performance_assessment/docs/com2014_215_final_en.pdf

23. European Observatory on Health Systems and Policies (2017). The health system and policy monitor: regulation. Retrieved January 10 2019 from https://www.who.int/ health-laws/countries/fra-en.pdf

24. European Union Agency for Fundamental Rights (2018). Fundamental Rights Report 2018. Retrieved January 15, 2019 from https://fra.europa.eu/en/publications-and-resources/publications/ annual-reports/fundamentalrights-2018

25. Guidelines International Network (2018). Library \& Resources/ International Guideline Library. Retrieved January 10, 2019 from https://www.g-i-n.net/library/ international-guidelines-library

26. Health Statistics Service of Ministry of Health of Ukraine (2019). Cтатистичні дані [Statystychni dani]. Retrieved January 18, 2019 from http://medstat.gov.ua/ukr/ statdan.html

27. iFactor (2018). Кодекс законов о труде Украины [Kodeks zakonov o trude Ukrainy]. Retrieved January 18, 2019 from https://i.factor. ua/law-39/

28. iFactor (2019). Кодекс Украинь об административных правонарушениях [Kodeks Ukrainy ob administrativnykh narusheniyakh]. Retrieved January 18, 2019 from https://i.factor.ua/ law-41/

29. Ivanova, Ye. (2018). Почему Украина оказалась на 97 месте в рейтинге здоровья ВОЗ [Pochemu Ukraina okazalas na 97 meste $v$ reytinge zdorovia VOZ]. Retrieved January 13, 2019, from https://novosti-n.org/analitic/ $\mathrm{read} / 3303 . \mathrm{html}$

30. Konoval, S., \& Gul, T. (2018). Оклады в бюджетной сфере с 1 января 2018 года [Oklady v biudzhetnoy sfere s 1 yanvarya 2018 goda]. Оплата труда [Oplata truda]. Retrieved January 11, 2019 from https://i.factor.ua/ journals/ot/2018/january/issue-1/ article-33300.html

31. Kozachenko, O. (2018) Украинская нация хиреет от болезней и нищеты [Ukrainskaya natsiya khireyet ot bolezney i nishchety]. Retrieved January 14, 2019 from https://www.politnavigator. net/ukrainskaya-naciya-khireetot-boleznejj-i-nishhety-kievskijjzhurnal.html

32. LigaZakon (2017a). О первичной медицинской помощи на приницпах семейной медицины. Проект закона Украины от 22.06.2017 № 6634 [O pervichnoy meditsinskoy pomoshchi na printsipakh semeynoy meditsiny. Proekt zakona Ukrainy ot 22.06.2017 № 6634]. Retrieved January 16, 2019 from http://search.ligazakon.ua/__ doc2.nsf/link1/JH54A00A.html

33. LigaZakon (2017b). О повышении доступности и качества медичинского обслуживания в сельской местности. Проект закона Украины от 18.09.2017 № 7117 [O povyshenii dostupnosti $i$ kachestva meditsinskogo obsluzhivaniya $v$ selskoy mestnosti]. Retrieved January 16, 2019 from http://search.ligazakon.ua/1_doc2. nsf/link1/JH5HP00V.html

34. LigaZakon (2018). О врачебном самоуправлении. Проект закона Украины от 06.04.2018 № 8250 [O vrachebnom samoupravlenii. Proekt zakona Ukrainy ot 06.04.2018 No. 8250]. Retrieved January 18, 2019 from http:// search.ligazakon.ua/l_doc2.nsf/ link1/JH6D600A.html

35. Ministry of Finance of Ukraine (2018). Расходы госбюджета Украины [Raskhody gosbiudzheta Ukrainy]. Retrieved January 11, 2019 from https://index.minfin. com.ua/finance/budget/gov/expense/
36. Ministry of Health of Ukraine (1997). Про подальше удосконалення атестаціі лікарів. Наказ МОЗ України від 19.12.1997 № 359 [Pro podalshe udoskonalennia atestatsii likariv. Nakaz MOZ Ukrainy vid 19.12.1997 No. 359]. Retrieved January 18, 2019 from https://zakon. rada.gov.ua/laws/show/z0014-98

37. Ministry of Health of Ukraine (2012a). Методика розробки та впровадження медччних стандартів медичної допомоги на засадах доказової медицини. Наказ Міністерства охорони здоров'я України № 751 від 28.09.2012 [Metodyka rozrobky ta vprovadzhennia medychnykh standartiv medychnoi dopomohy na zasadakh dokazovoi medytsyny. Nakaz Ministerstva okhorony $z$ dorovia Ukrainy No. 751 vid 28.09.2012]. Retrieved January 10, 2019 from https://zakon.rada.gov. ua/laws/show/ru/z2001-12\#n22

38. Ministry of Health of Ukraine (2012b). Про порядок контролю якості медичної допомоги. Наказ МОЗ України від 28.09.2012 № 752 [Pro poriadok kontroliu yakosti medychnoi dopomohy. Nakaz MOZ Ukrainy vid 28.09.2012 No. 752]. Retrieved January 18, 2019 fromhttps:// zakon.rada.gov.ua/laws/show/ z1996-12

39. Ministry of Health of Ukraine (2016). Про внесення змін до наказу Міністерства охорони здоров'я України від 28 вересня 2012 року № 751 [Pro vnesennia zmin do nakazu Ministerstva okhorony zdorovia Ukrainy vid 28 veresnia 2012 roku No. 751]. Retrieved January 10, 2019 from https://zakon3.rada.gov.ua/laws/ show/z0530-17?lang=ru

40. Ministry of Public Health, Welfare and Sport (2016). Healthcare in the Netherlands. Retrieved January 10, 2019 from https://www.eiseverywhere.com/file_uploads/0f57 b7c2d0d94ff45769269d5087690 5_P4-HealthcareintheNetherlands. pdf

41. Murphy, J., Lawton, E., \& Sandel, M. (2015). Legal Care as Part of Health Care: The Benefits of Medical-Legal Partnership. 
Pediatric Clinics of North America, 62(5), 1263-1271. https://doi. org/10.1016/j.pcl.2015.06.001

42. National Anti-Corruption Bureau of Ukraine (2018). Розслідування НАБУ у соиіальній сфері [Rozsliduvannia NABU u sotsialnii sferi]. Retrieved January 11, 2019 from https://nabu.gov.ua/ novyny/90-zlovzhyvan-vykrytyhnabu-u-socialniy-sferi-stosuyutsya-ohorony-zdorovya

43. Numbeo (2019). Health Care Index for Country. Retrieved January 13, 2019 from https://www. numbeo.com/health-care/rankings_by_country.jsp

44. Obozrevatel.ua (2018). Cmapm медребормы: какие трудности ждут украинцев в больницах [Start medreformy: kakie trudnosti zhdut ukraintsev $v$ bolnitsakh]. Retrieved January 17, 2019 from https://www.obozrevatel.com/ health/start-medreformyi-kakietrudnosti-zhdut-ukraintsev-vbolnitsah.htm

45. OECD (2019). Health expenditure and financing. Retrieved January 10, 2019 from https://stats.oecd.org/Index. asp $x$ ?DataSetCode=SHA\&_ga$=2.10458422 .2014736280 .154-$ 5335206-1943594881.1540039091

46. Official Journal of the European Union (2014). Association agreement between the European Union and its Member States, of the one part, and Ukraine, of the other part. Retrieved January 10, 2019 from https://trade.ec.europa.eu/ doclib/docs/2016/november/tradoc_155103.pdf

47. Pierre, A., \& Jusot, F. (2017). The likely effects of employermandated complementary health insurance on health coverage in France. Health Policy, 121(3), 321-328. https://doi.org/10.1016/j. healthpol.2016.12.004

48. Poniakina, S., \& Shevchuk, P. (2017). About Ukraine Data on Causes of Death. Retrieved January 11, 2019 from https:// www.causesofdeath.org/Data/ UKR/20160121/UKR_bd.pdf

49. Ponto, J. (2015). Understanding and Evaluating Survey Research.
Journal of the Advanced Practitioner in Oncology, 6(2), 168-171. Retrieved from https://www. ncbi.nlm.nih.gov/pmc/articles/ PMC4601897/

50. Portal of the Publications Office of the EU (2012). Charter of Fundamental Rights of the European Union2012/C 326/02. Retrieved January 15, 2019 from https:// eur-lex.europa.eu/eli/treaty/ char_2012/oj

51. Rating Group Ukraine (2016). Состояние медицинской сферы в Украине [Sostoyanie meditsinskoy sfery $v$ Ukraine]. Retrieved January 18, 2019 from http:// ratinggroup.ua/ru/research/ ukraine/sostoyanie_medicinskoy_sfery_v_ukraine.html

52. Rodwin, V. (2018). The French health care system. World Hospitals and Health Services - Universal Health Coverage (UHC): Making progress towards the 2030 targets, 54(1). Retrieved January 18, 2019 from https://wagner.nyu. edu/files/faculty/publications/ French.health.system.03.2018\%20 \%281\%29.pdf

53. State Statistics Service of Ukraine (2018). Захворюваність населення [Zakhvoriuvanist naselennia]. Retrieved January 10 , 2019 from http://www.ukrstat.gov. ua/operativ/operativ2007/oz_rik/ oz_u/zahvor_06_u.htm

54. State Statistics Service of Ukraine (2019). Retrieved January 11, 2019 from http://www.ukrstat. gov.ua/

55. Statistisches Bundesamt (Destatis) (2019). Health expenditure. Retrieved January 10, 2019 from https://www.destatis.de/EN/ Home/_node.html

56. Sun, L.-Y., Lee, E.-W., Zahra, A., \& Park, J.-H. (2015). Should non-citizens have access to publicly funded health care? A study of public attitudes and their affecting factors. Public Health, 129(9), 1157-1165. https://doi. org/10.1016/j.puhe.2015.07.033

57. The Commonwealth Fund (2019a). The Dutch Health Care System. Retrieved January 10 2019 from https://international. commonwealthfund.org/countries/netherlands/
58. The Commonwealth Fund (2019b). The English Health Care System. Retrieved January 10, 2019 from https://international. commonwealthfund.org/countries/england/

59. The Commonwealth Fund (2019c). The French Health Care System. Retrieved January 10, 2019 from https://international.commonwealthfund.org/countries/france/

60. The Commonwealth Fund (2019d). The German Health Care System. Retrieved January 10, 2019 from https://international. commonwealthfund.org/countries/germany/

61. The National Archives (2012). Health and Social Care Act. Retrieved January 10, 2019 from http://www.legislation.gov.uk/ ukpga/2012/7/contents/enacted/ data.htm

62. The National Center for Biotechnology Information (NCBI) (2018). Health care in Germany: The German health care system. Retrieved January 10, 2019 from https://www.ncbi.nlm.nih.gov/ books/NBK298834/

63. The Statistics Portal (2019). National Health Service (NHS) UK - Statistics \& Facts. Retrieved January 10, 2019 from https:// www.statista.com/topics/3128/ national-health-service-nhs-uk/

64. Ukrainian National BAR Association. (2012). Положення про Раду адвокатів України. ВКДКА; Положення, Витяг від 17.11.2012 [Polozhennia pro Radu advokativ Ukrainy. VKDKA; Polozhennia, Vytiah vid 17.11.2012]. Retrieved January 18, 2019 from https:// zakon.rada.gov.ua/rada/show/ n0001418-12?lang $=$ ru

65. Verkhovna Rada of Ukraine (1992). Основы законодательства Украинь о здравоохранении. Закон Украины от 19.11.1992 № 2801-XII [Osnovy zakonodatelstva Ukrainy o zdravookhranenii. Zakon Ukrainy ot 19.11.1992 № 2801-XII]. Retrieved January 14, 2019 from http://kodeksy.com. ua/ka/osnovy_zakonodatelstva_ ukrainy_o_zdravoohranenii.htm 
66. Verkhovna Rada of Ukraine (1996). Конституция Украинь [Konstitutsiya Ukrainy]. Retrieved January 12, 2019 from http:// iportal.rada.gov.ua/uploads/documents/27396.pdf

67. Verkhovna Rada of Ukraine (2011). Податковий кодекс України [Podatkovyi kodeks Ukrainy]. Retrieved January 18, 2019 from https://zakon.rada.gov. ua/laws/show/2755-17?lang=ru

68. Verkhovna Rada of Ukraine (2015). Про тіцензування видів господарської діяльності. Закон України від 02.03.2015 № 222VIII [Pro litsenzuvannia vydiv hospodarskoi diialnosti. Zakon Ukrainy vid 02.03.2015 No. 222VIII]. Retrieved January 18, 2019 from https://zakon.rada.gov.ua/ laws/show/222-19

69. Verkhovna Rada of Ukraine (2016). Про виконавче провадження. Закон України від 02.06.2016 № 1404-VIII [Pro vykonavche provadzhennia. Zakon Ukrainy vid 02.06.2016 № 1404-VIII]. Retrieved January 18, 2019 from https://zakon.rada.gov. ua/laws/show/1404-19?lang=ru

70. Verkhovna Rada of Ukraine (2017а). О государственных финансовых гарантиях медицинского обслуживания населения. Закон Украины om 19.10.2017 № 2168-VIII [O gosudarstvennykh finansovykh garantiyakh meditsinskogo obsluzhyvaniya naseleniya. Zakon Ukrainy ot 19.10.2017 № 2168VIII]. Retrieved January 14, 2019 from http://kodeksy.com.ua/ka/o_ gosudarstvennyh_finansovyh_garantiyah_meditsinskogo_obsluzhivaniya_naseleniya.htm

71. Verkhovna Rada of Ukraine (2018). О Государственном бюджете Украины на 2019 год. Закон Украины от 23.11.2018 2. N 2629-VIII [O Gosudarstvennom biudzhete Ukrainy na 2019 god. Zakon Ukrainy ot 23.11.2018 g. No. 2629-VIII]. Retrieved January 14, 2019 from https://www. profiwins.com.ua/ru/legislation/ project/13708.html

72. Verkhovna Rada of Ukraine. (2017b). Про аудит бінансовоі звітності та аудиторсвку діяльність. Закон України від
21.12.2017 № 2258-VIII [Pro audit finansovoi zvitnosti ta audytorcku diyalnist. Zakon Ukrainy vid 21.12.2017 № 2258-VIII]. Retrieved January 18, 2019, from https://zakon.rada.gov.ua/laws/ show/2258-19?lang=ru

73. Vogler, S. (2018). Access to High-Cost Medicines in Europe. Equitable Access to High-Cost Pharmaceuticals, 143-164.

74. World Health Organization (2018) Noncommunicable diseases country profiles 2018. Retrieved January 18, 2019 from https://www.who. int/nmh/publications/ncd-profiles-2018/en/

75. World Health Organization (2019a). Crude death rate per 1000 population. Retrieved January 10, 2019 from https://gateway.euro. who.int/en/indicators/hfa_220070-crude-death-rate-per1000-population/visualizations/\#i $\mathrm{d}=18829 \& \mathrm{tab}=$ table

76. World Health Organization (2019b). Data and statistics. Retrieved January 18, 2019 from http://www.euro.who.int/en/ health-topics/Health-systems/ patient-safety/data-and-statistics

77. World Health Organization (2019c). Estimated maternal mortality per 100000 live births (WHO/UNICEF/UNFPA estimates). Retrieved January 10, 2019 from https://gateway.euro.who.int/ en/indicators/hfa_97-1220-estimated-maternal-mortality-per100-000-live-births-whounicefunfpa-estimates/

78. World Health Organization (2019d). Estimated probability of dying before age 5, per 1000 live births (world health report). Retrieved January 10, 2019 from https:/gateway.euro.who.int/en/ indicators/hfa_64-1073-estimated-probability-of-dying-beforeage-5-per-1000-live-births-worldhealth-report/

79. World Health Organization (2019e). Global Health Observatory (GHO) data. Retrieved January 10, 2019 from https://gateway.euro. who.int/en/

80. World Health Organization (2019f). Health expenditures. Retrieved January 10, 2019 from https:/gateway.euro.who.int/ en/indicators/h2020_30-healthexpenditures/

81. World Health Organization (2019g). SDR all causes, all ages, per 100 000. Retrieved January 10 2019 from https://gateway.euro. who.int/en/indicators/hfa_1941810-sdr-all-causes-all-agesper-100-000/

82. World Health Organization (2019h). SDR, all causes, 0-64, per 100 000. Retrieved January 10, 2019 from https://gateway. euro.who.int/en/indicators/ hfamdb_101-sdr-0-64-all-causesper-100-000/

83. World Health Organization (2019i). SDR, cancer of the cervix uteri, all ages, per 100000. Retrieved January 10, 2019 from https:/gateway.euro.who.int/en/ indicators/hfa_144-1560-sdr-cancer-of-the-cervix-uteri-all-agesper-100-000/

84. World Health Organization (2019j). SDR, external causes of injury and poisoning, all ages, per 100 000. Retrieved January 10, 2019 from https://gateway.euro. who.int/en/indicators/hfa_1581720-sdr-external-causes-ofinjury-and-poisoning-all-agesper-100-000/

85. World Health Organization (2019k). SDR, tuberculosis, all ages, per 100 000. Retrieved January 10 , 2019 from https://gateway.euro. who.int/en/indicators/hfa 2841930-sdr-tuberculosis-all-agesper-100-000/

86. World Population Review (2018). Life Expectancy by Country 2017. Retrieved from http://worldpopulationreview.com/

87. Интерактивная бухгалтерия [Interaktivnaya bukhgalteriya]. (2019). ЕTC-2019: должностные оклады, индексация и корректировка среднего заработка [ETS-2019: dolzhnostnyye oklady, indeksatsiya i korrektirovka srednego zarabotka]. Retrieved January 17, 2019 from http:// www.interbuh.com.ua/ru/documents/ib/9034/126317?_ga=2.1 45536692.1618503354 .1547 806643-1763642156.1547806643 
88. Сегодня [Segodnya] (2018b). Личный врач, электронная медицина и большие зарплать: как медреформа изменила жизнь в 2018 году [Lichnyy vrach, elektronnaya meditsina $i$ bolshie zarplaty: kak medreforma izmenila zhizn $v 2018$ godu]. Retrieved January 17, 2019 from https://www.segodnya.ua/ ukraine/lichnyy-vrach-elektronnaya-medicina-i-bolshiezarplaty-kak-medreforma-izmenila-zhizn-v-2018-1201320.html
89. Сегодня [Segodnya]. (2018a). Какой будет медреборма в Украине в 2019 году: новые лимиты и платные узкие специалисты [Kakoy budet medreforma $v$ Ukraine $v 2019$ godu: novye limity i platnye uzkie spetsialisty]. Retrieved January 17 2019 from https://www.segodnya. ua/ukraine/kakoy-budet-medreforma-v-ukraine-v-2019-godunovye-limity-i-platnye-uzkiespecialisty-1197378.html

90. Страна.ua [Strana.ua] (2017). Лекарства в Украине продаются с наценкой в $300 \%$ по сравнению с соседними странами [Lekarstva $v$ Ukraine prodayutsya s natsenkoy $\checkmark 300 \%$ po sravneniu s sosednimi stranami]. Retrieved January 9, 2019, from https://strana.ua/ articles/interview/63486-kakekonomiya-privodit-ukraincev-nachernyj-rynok-lekarstv.html

91. Уголовный Кодекс Украины [Ugolovnyy kodeks Ukrainy] (2001). Retrieved January 17, 2019 from https://online.zakon.kz/ Document/?doc id=30418109 